
Lewallen, C. G., Rall, J. E., and Berman, M. (1959). J. clin.

Lewis, L. A., and McCullagh, E. P. (1944). Amer. J. med. Sci., 208, 727.

Lillington, G. A., Gastineau, C. F., and Underdahl, L. O. (1959). Proc. Mayo Clin., 34, 605

Luxton, R. W., and Cooke, R. T. (1956). Lancet, 2, 105.

McAlpine, S. G. (1955). Ibid., $2,58$.

Maclagan, N. F. (1944). Brit. J. exp. Path., 25, 234.

- (1947). Brit. med. J., 2. 197.

Mahaux, J., and Pirart, J. (1959). Acta clin. belg., 14, 59.

Man, E. B., Gildea, E. F., and Peters, J. P. (1940). J. clin. Invest., 19, 43.
Prunty, F. T. G., McSwiney, R. R., and Hawkins, J. B. (1959). A Laboratory Manual of Chemical Pathology. Pergamon Press, London

Roitt, I. M., Campbell, P. N., and Doniach, D. (1958). Biochem. J., 69, 248

and Doniach, D. (1958). Lancet, 2, 1027.

Shulman, S., Rose, N. R., and Witebsky, E. (1960). J. Lab. clin. Med., 55, 733.

Skillern, P. G., Crile, G., jun., McCullagh, E. P., Hazard, J. B., Lewis, L. A., and Brown, H. (1956), J. clin. Endocr., 16, 35. Wayne, E. J. (1960). Brit. med. J., 1, 1, 78.

Westergren. A. (1921). Acta med. scand., 54, 247.

\title{
HAEMORRHAGE ASSOCIATED WITH THROMBOCYTOPENIA IN MEGALOBLASTIC ANAEMIA
}

\author{
MARY D. SMITH,* M.D., F.R.F.P.S. \\ M.R.C.P.Ed. \\ Senior Registrar in Haematology
}

BY

\author{
D. A. SMITH, $\dagger$ M.B., Ch.B., B.Sc. \\ Senior House Officer in Pathology
}

AND

\author{
M. FLETCHER, $*$ M.B., Ch.B., F.R.F.P.S. \\ Registrar in Medicine
}

From the Department of Haematology, the Royal Infirmary, Glasgow

Reduction in the platelet count is widely recognized as part of the dyshaemopoietic pattern in megaloblastic anaemia. The possible presentation of a megaloblastic anaemia as a haemorrhagic diathesis due to thrombocytopenia is, however, much less commonly appreciated and forms the subject-matter of this communication. Six cases were seen by us over a three-year period and three others are included by courtesy of Dr. J. L. Markson of Stobhill General Hospital, Glasgow.

\section{Cases}

The outstanding clinical features and relevant laboratory data are presented in Tables I and II, the cases being grouped according to the final diagnosis made.

Haemorrhagic Features.-All the patients were either admitted to hospital because of a haemorrhagic syndrome or developed haemorrhagic features of alarming degree shortly after admission. The main source of bleeding varied, but in each the history and clinical features also revealed evidence of a generalized haemorrhagic tendency. In Case 1 haemorrhage was from all mucosal surfaces. It was excessively severe, and was associated with a puffy pallid appearance and an initial lack of response to vitamin $B_{12}$ and folic acid. At the time the clinical state even raised the possibility of leukaemia, and myeloid hyperplasia (described later) lent some support to this suspicion. Three cases had haematemesis and melaena (Nos. 2, 5 , and 7 ), and in two of these there were also epistaxis and purpura (Cases 5 and 7). Uncontrollable epistaxis was associated with haematuria in Case 4, and one patient (Case 6) was admitted on separate occasions for post-partum haemorrhage and epistaxis. In Case 3 the bed was soaked with blood from the site of an intramuscular injection, and questioning elicited a history of epistaxis a few days earlier. Confluent purpura

*Now at Department of Haematology, Stobhill General Hospital, Glasgow.

+Now at Department of Medicine, Gardiner Institute, Western Infirmary, Glasgow.

‡Now at Gartloch Hospital, Gartcosh, near Glasgow. dominated in Case 9, but melaena was a further feature, and in Case 8 haematuria occurred and was accompanied by epistaxis.

Other Clinical Features.-The history indicated an insidious onset of weakness compatible with anaemia in several instances, and Cases 3 and 4 had been admitted for investigation of possible alimentary neoplasm, but it was haemorrhage in every instance which directed attention to the blood picture, and the significance of any prodromal weakness had not been fully appreciated. In Case 2 the diagnosis of pernicious anaemia had previously been made and megaloblastic anaemia as the cause of his haematemesis was quite unsuspected. The " anahaemin" he had been receiving was found to have a negligible vitamin- $B_{12}$ content (assay by Dr. D. 'L. Mollin of the Postgraduate Medical School of London). In Case 8 haematuria occurred during a state of severe post-partum collapse with suppression of urine and gross electrolyte imbalance. In two cases the spleen was slightly enlarged; in the others it was not palpable.

Blood Picture and Sternal Marrow.-Peripheral blood examination revealed varying degrees of macrocytosis and marked thrombocytopenia. The platelet count was $37,000 / \mathrm{c} . \mathrm{mm}$. or under in eight cases and was $71,000 /$ c.mm. in the remaining case. Sternal-marrow aspiration disclosed frankly megaloblastic erythropoiesis in all cases. Erythropoiesis was also of notably immature type and sometimes was accompanied by granular-cell hyperplasia with the presence of giant myelocytes. In Case 1 the myeloid hyperplasia was excessive and indeed was questioned as leukaemic, but myeloblasts were not prominent and the megaloblastic reaction was flagrant. In two instances (Cases 4 and 8) megakaryocytes were absent ; in the others they were present and appeared normal.

Further Diagnostic Features.-Further investigations indicated several different types of megaloblastic state (Table II). Cases 1, 2, and 3 were diagnosed as Addisonian pernicious anaemia and have been maintained in full remission on intramuscular vitamin $\mathbf{B}_{12}$. Addisonian pernicious anaemia was also the 
probable diagnosis in Case 4, where early death occurred and gastric mucosal atrophy was found at necropsy. In Case 5 a malabsorption syndrome existed with impaired assimilation of folic acid; in retrospect, this may even be suspected of having been an underlying cause in her first illness, which was characterized by weakness and subsequently haematemesis, and was treated by blood transfusion and iron without marrow examination being performed. Case 6,7 , and 8 were clearly associated with pregnancy. They responded completely to folic acid. Such additional investigations as were carried out are supportive of megaloblastic anaemia of pregnancy. In Case 9 the eventual evidence suggested megaloblastic anaemia due to primidone, but vitamin $B_{12}$ was given urgently at the start because of her critical condition. This was continued, and it is interesting that she did in fact respond completely to it.
Course after Treatment.-Blood transfusion was given to eight of the nine cases and haematinic treatment often initiated with multiple therapy because of the critical states. In all instances (except Case 4, who died) there was cessation of haemorrhage and complete haematological recovery. The platelet count rose fairly promptly and steeply except in Case 1, where there was initial delay. In two instances it actually temporarily reached levels above normal-843,000 and 660,000/ c.mm. in Cases 6 and 7 respectively, and both on the ninth day. The initial rise in platelets occurred more or less simultaneously with the reticulocyte crisis but several times was much more dramatic.

\section{Discussion}

Although haemorrhagic manifestations are well known in megaloblastic anaemia they are usually regarded as

Table 1.-Clinical Features, Peripheral Blood, and Bone-marrow Picture

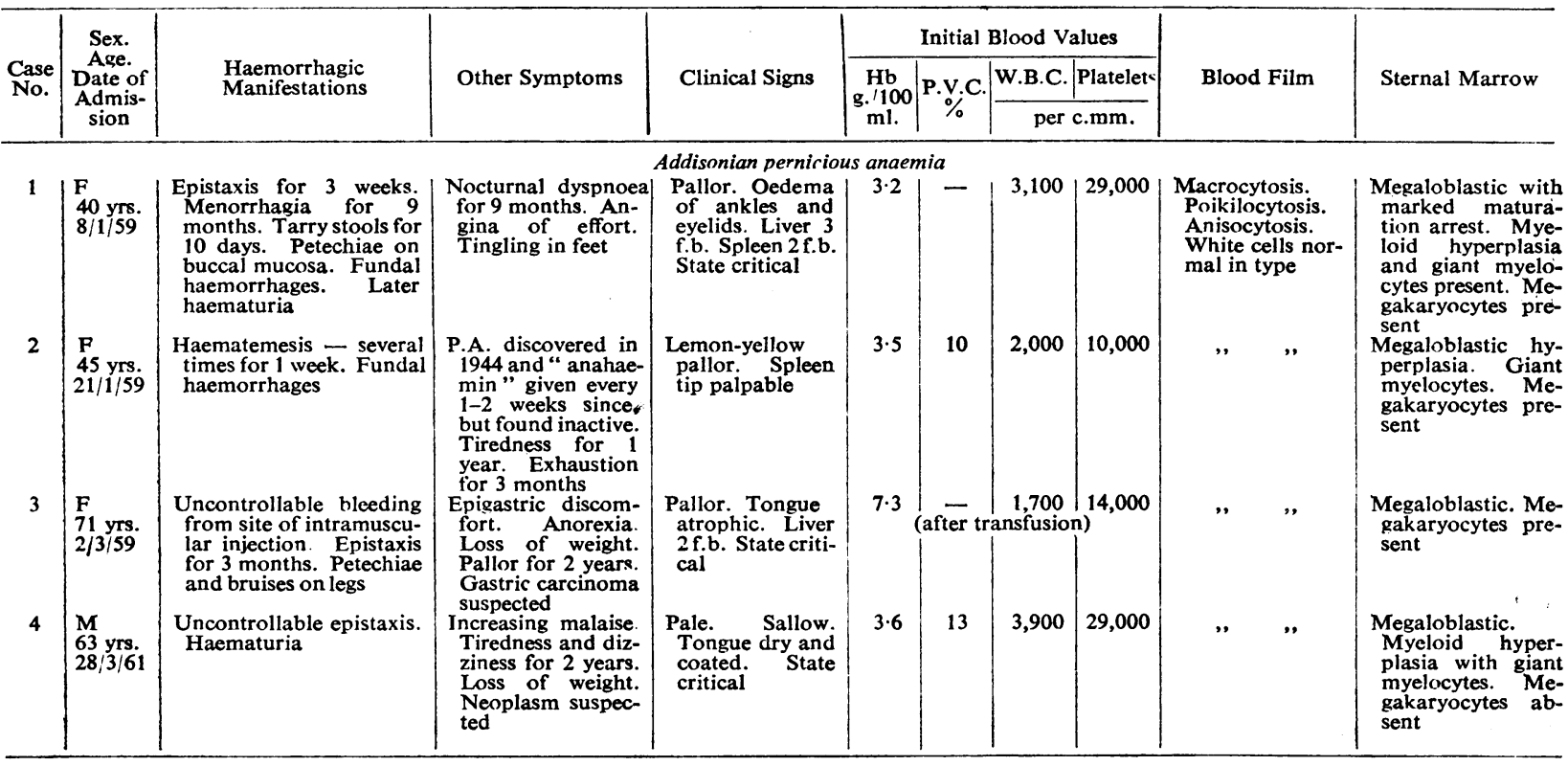

Malabsorption syndrome

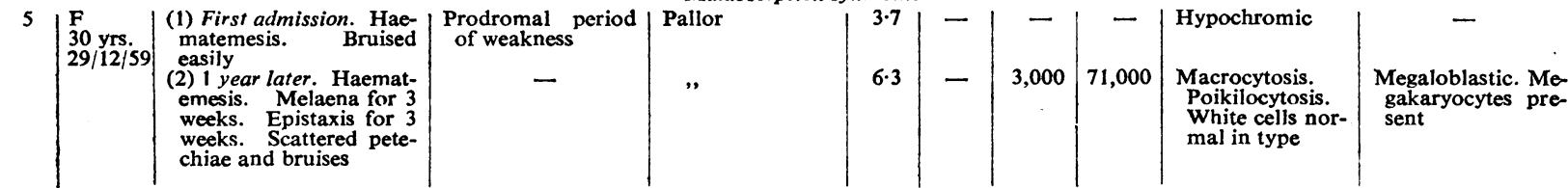

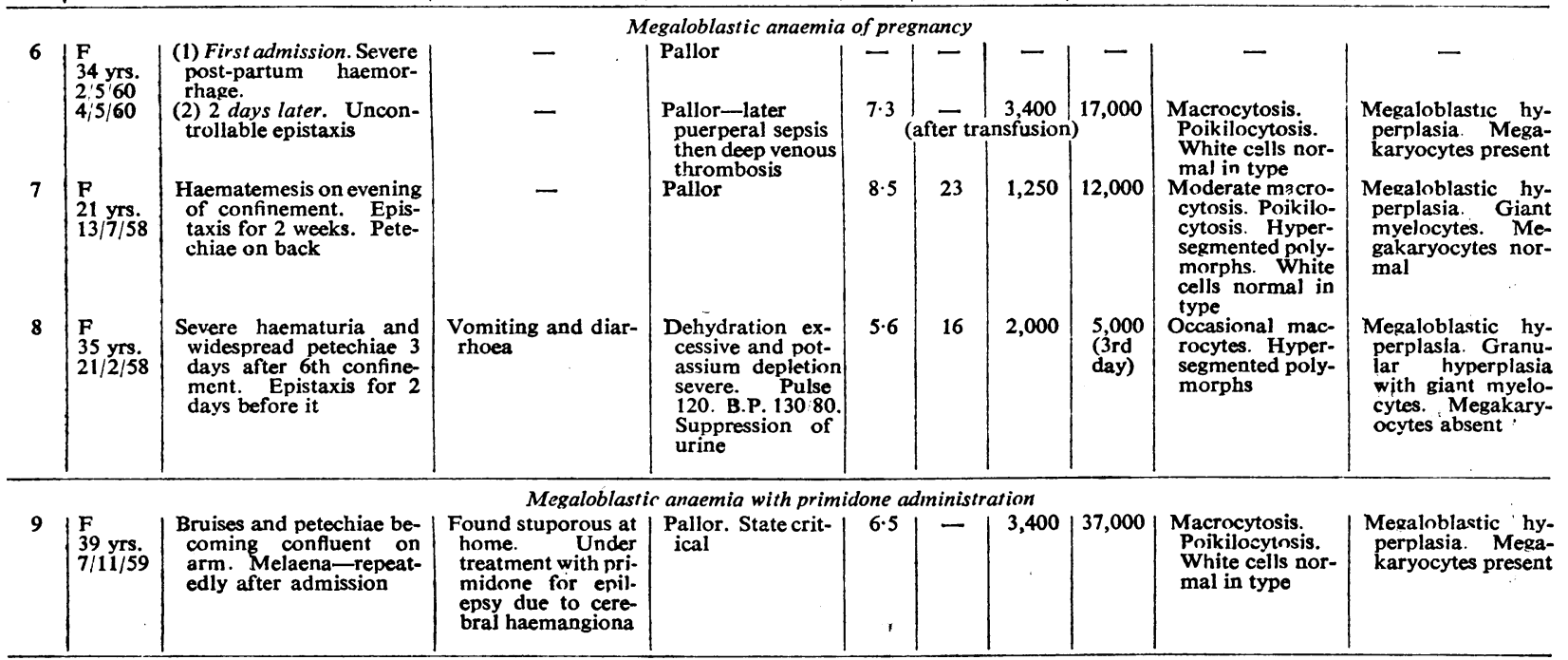


being of mild degree and their association with thrombocytopenia has often been a tentative suggestion. From time to time the coincident occurrence of severe haemorrhagic manifestations and thrombocytopenia has been reported, but the most convincing correlation of haemorrhagic features in megaloblastic anaemia with thrombocytopenia is by Cosnett and Macleod (1959). In a study of retinal haemorrhages in anaemia they demonstrated the association of such haemorrhages first with megaloblastic rather than with the iron-deficiency anaemia, and then, in the megaloblastic group, with low rather than with normal platelet counts.

Biermer actually observed a high incidence of retinal haemorrhages and cutaneous petechiae when he gave his description of pernicious anaemia in 1872 ; he also commented on occasional severe gastro-intestinal bleeding and genito-urinary bleeding (quoted from Bisgeier, 1954). Minot (1918) commented on thrombocytopenia and observed that "the development of purpura haemorrhagica in pernicious anaemia, even though it be manifested by only a slight oozing of the gums, is a serious symptom." His comment related to prognosis rather than to any acute episode. He did, however, describe one case of extensive serious purpura haemorrhagica, but did not mention bleeding from mucosal surfaces. Dyke and Stewart (1931) actually emphasized the absence of bleeding in five cases of pernicious anaemia with thrombocytopenia, and a similar observation was made by Schwartz (1944). On the other hand, alarming bleeding occurring as epistaxis and attributed to thrombocytopenia in pernicious anaemia was reported by Torrey (1933) and by Bisgeier (1954). In the latter instance the patient also presented severe bleeding from the gums and gross haematuria. After administration of liver extract the platelet count rose promptly to $375.000 / \mathrm{c} . \mathrm{mm}$. and the bleeding stopped. Revol and Payen (1953), trying to assess the incidence of haemorrhagic complications in pernicious anaemia, found two instances of a haemorrhagic syndrome in 82 cases, and one of these had severe thrombocytopenia.

Davis and Brown (1953) state in relation to pernicious anaemia that platelets are usually reduced in number but seldom below $50,000 / \mathrm{c} . \mathrm{mm}$. They record the occurrence of retinal haemorrhages in about $5 \%$ of their cases, and of haemorrhage in the brain, skin, uterus, and rectum on rare occasions. They also mention the occurrence of haemorrhage in steatorrhoea, especially non-tropical sprue. They do not clearly relate bleeding to thrombocytopenia in any of these instances, but discuss platelet deficiency, anoxia, and low " prothrombin levels" as probable contributory factors. Among standard textbooks, Whitby and Britton (1957) comment that platelets are always reduced in severe cases of pernicious anaemia, and hypoprothrominaemia may occur. Wintrobe (1956) writes that in severe vitamin- $B_{12}$ and folic-acid deficiency there may be a thrombocytopenia of less that $100,000 / \mathrm{c} . \mathrm{mm}$. and this may on occasion be associated with purpura and an increased bleeding-time. De Gruchy (1958) also records thrombocytopenia in megaloblastic anaemia but remarks that it is rarely severe enough to cause haemorrhagic manifestations. It is, however, current postgraduate teaching in several centres that severe haemorrhage due to thrombocytopenia constitutes almost the only presentday hazard in megaloblastic anaemia and requires blood transfusion.

The possible severity of haemorrhage in megaloblastic anaemia and its association with thrombocytopenia is clearly borne out in the present group of cases, and the emergency of the situation to the point of requiring blood transfusion is readily appreciated. It is noteworthy that megaloblastic anaemia was scarcely suspected of being the underlying cause of the bleeding until the peripheral blood picture raised suggestive evidence or the marrow puncture had been performed.

In all the patients, treatment with vitamin $B_{12}$ and/or folic acid brought about cessation of haemorrhage and complete haematological recovery. Whether or not steroid therapy when it was given contributed to stopping the bleeding is a matter of surmise, but it is probably more rational to use steroids judiciously than to damp responses with excessive blood transfusion. "White leg" developed in Case 6 when the platelet count was over $800,000 /$ c.mm., and a coronary infarction in Case 4 at the time of platelet rise (total platelet count not done). Both had predisposing causes in pregnancy and atheroma respectively, but thrombocythaemia may have been a contributory factor in these thrombotic complications. Vitamin $\mathrm{C}$ was given empirically in Case 1 and Case 3 because of the emergency, but there were no grounds for suspecting vitamin-C deficiency.

TABLE II.-Further Diagnostic Investigations and Treatment

\begin{tabular}{|c|c|c|c|c|c|c|c|c|c|}
\hline $\begin{array}{l}\text { Case } \\
\text { No. }\end{array}$ & $\begin{array}{l}\text { Bleeding- } \\
\text { time }\end{array}$ & $\begin{array}{c}\text { Hess's } \\
\text { Test }\end{array}$ & Gastric Juice & \begin{tabular}{|} 
Serum \\
Vit. $B_{12}$ \\
$\mu \mu \mathrm{g} . / \mathrm{ml}$
\end{tabular} & Schilling Test & $\begin{array}{c}\text { Fat } \\
\text { Balance }\end{array}$ & $\begin{array}{c}\text { Folic } \\
\text { Acid } \\
\text { Absorption }\end{array}$ & $\begin{array}{l}\text { Treatment-All Except } \\
\text { No. } 4 \text { received Blood } \\
\text { Transfusion }\end{array}$ & $\begin{array}{c}\text { Course-All Except } \\
\text { No. } 4 \text { Recovered } \\
\text { Completely }\end{array}$ \\
\hline 1 & ++ & 一 & $\begin{array}{l}\text { Histamine-fast } \\
\text { achlorhydria }\end{array}$ & 100 & - & - & - & $\begin{array}{l}\text { Vit. } B_{12} \text {, folic acid, vit. } \\
\text { C. ferrous sulphate. }\end{array}$ & $\begin{array}{l}\text { Sluggish respnnse initi- } \\
\text { ally: recovered }\end{array}$ \\
\hline 2 & 10 mins. & 一 & ", & 一 & No intrinsic factor & Normal & 一 & Folic acid, vit. $B_{12}$ & $\begin{array}{l}\text { Maintained well on } \\
\text { vit. } B_{18}\end{array}$ \\
\hline 3 & +++ & Pos. & ", & 110 & 一 & 一 & - & $\begin{array}{l}\text { Vit. } B_{12} \text {, folic acid, } \\
\text { ascorbic acid, predni- } \\
\text { sone }\end{array}$ & $\begin{aligned} \mathrm{V}_{18} & \text {, }\end{aligned}$ \\
\hline 4 & + & Neg. & $\begin{array}{l}\text { P.M. gastric } \\
\text { mucosal } \\
\text { atrophy }\end{array}$ & 一 & 一 & 一 & 一 & $\begin{array}{l}\text { Vit. } B_{12} \text {, folic acid, fer- } \\
\text { rous sulphate }\end{array}$ & $\begin{array}{l}\text { Reticulocyte response. } \\
\text { Died } 18 \text { ' } 5 \text { ' } 61 \text { of coron- } \\
\text { ary thrombosis (con- } \\
\text { firmed at P.M.) }\end{array}$ \\
\hline 5 & $\begin{array}{l}\text { Normal (after } \\
\text { giving folic } \\
\text { acid) }\end{array}$ & - & Free $\mathbf{H C l}$ & 325 & $\begin{array}{l}\text { Intrinsic factor pres- } \\
\text { ent and vit. } B_{12} \text { ab- } \\
\text { sorbed }\end{array}$ & Normal & Impaired & Vit. $B_{12}$, folic acid & Maintained on folic acid \\
\hline 6 & $\begin{array}{l}\text { Normal (after } \\
\text { transfusion) }\end{array}$ & Neg. & $"$ & 一 & - & 一 & 一 & Folic acid & $\begin{array}{l}\text { Recovery complicated } \\
\text { by "white leg when } \\
\text { platelets were } 847,000 / \\
\text { c.mm. }\end{array}$ \\
\hline $\begin{array}{l}7 \\
8\end{array}$ & 11 mins. & Pos. & "- & $\begin{array}{r}60 \\
200\end{array}$ & $=$ & 二 & 二 & ", & $\begin{array}{l}\text { Recovery } \\
\text { Electrolyte imbalance } \\
\text { corrected. Ultimate } \\
\text { complete recovery }\end{array}$ \\
\hline 9 & $3 \frac{1}{2}$ mins. & 一 & Free $\mathbf{H C l}$ & 一 & $\begin{array}{l}\text { Intrinsic factor pre- } \\
\text { sent and vit. } \mathbf{B}_{12} \\
\text { absorbed }\end{array}$ & 一 & Normal & Vit. $\mathbf{B}_{12}$ & $\begin{array}{l}\text { Still on vit. } B_{1 y} \text {. Primi- } \\
\text { done reflaced by me } \\
\text { tharbital }\end{array}$ \\
\hline
\end{tabular}


It is of interest that the haemorrhagic episodes recorded occurred in several varieties of megaloblastic anaemia-Addisonian pernicious anaemia, megaloblastic anaemia of pregnancy, malabsorption due to steatorrhoea, and megaloblastic anaemia associated with primidone administration. This supports the conception that thrombocytopenia is part of the dyshaemopoietic state produced by lack of vitamin $B_{12}$ or folic acid and is not an independent feature. Other factors may have contributed to the haemorrhagic tendency, but unfortunately they were not investigated in any detail in our patients. Hypoprothrombinaemia has been described in pernicious anaemia. In itself it is unlikely to be severe enough to account for haemorrhage (Warner and Owen, 1942), but it can form a contributory cause. Where intestinal malabsorption exists lack of vitamin $\mathbf{K}$ may likewise contribute to a bleeding tendency.

These cases are reminders that post-partum blood loss, epistaxis, haematemesis, haematuria, and confluent purpura can have as their basis a megaloblastic anaemia. Thrombocytopenia is a significant factor in accounting for the bleeding and, like the anaemia, is corrected by vitamin $B_{12}$ or folic acid. The condition is initially critical and usually calls for blood transfusion before haematinics can take effect.

\section{Summary}

Nine cases of haemorrhagic emergencies found attributable to thrombocytopenia associated with various forms of megaloblastic anaemia are described. Eight of the patients required blood transfusion and subsequently recovered on vitamin- $B_{12}$ or folic-acid therapy. One responded to vitamin $B_{12}$ but died with a coronary infarction.

We are indebted to the following physicians and obstetricians for access to their patients and records: Professor L. J. Davis, Dr. A. H. Imrie, and Dr. E. G. Oastler, of the Royal Infirmary, Glasgow, and Dr. W. Armstrong, of Robroyston Hospital, Glasgow.

\section{REFERENCES}

Bisgeier, G. P. (1954). J. med. Soc. N.J.. 51, 94.

Cosnett, J. E., and Macleod, I. N. (1959). Brit. med. J., 2, 1002

Davis, L J., and Brown, A. (1953). The Megaloblastic Anaemias. Blackwell, Oxford.

De Gruchy, G. C. (1958). Clinical Haematology in Medical Practice. Blackwell, Oxford

Dyke, S. C., and Stewart, W. (1931). Lancet, 1, 1080.

Minot, G. R (1918). Med. Clin. N. Amer., 1, 1103.

Revol and Payen, (1953). Lyon méd., 189, 293.

Schwartz, S. O. (1944). Med. Clin. N. Amer., 28, 214.

Torrey, R. G. (1933). Ibid., 17, 603

Warner, E. D., and Owen, C. A. (1942). Amer. J. med. Sci., 203, 187

Whitby, L. E. H., and Britton, C. J. C. (1957). Disorders of the Blood, 8th ed. Churchill, London.

Wintrobe, M. M. (1956). Clinical Haematology, 4th ed. (rev.). Kimpton, London.

Research in Public Health Administration is a selection of abstracts compiled by the Research in Public Health Administration Project, School of Hygiene and Public Health, Johns Hopkins University, 615 North Wolfe Street, Baltimore 5. Maryland, U.S.A. The booklet is divided into the following sections: appropriate quotations and definitions; philosophy, principles, and problems; areas of research in public health administration; administration of research programmes; role of the Health Department; and role of the social sciences. The section of appropriate quotations includes Lord Rutherford's, "We haven't any money; we've got to think." A few copies are available free of charge from Assistant Professor C. M. WYLIE, at the address given above.

\section{ABSORPTION OF FOLIC ACID AND D-XYLOSE AS TESTS OF SMALL- INTESTINAL FUNCTION}

BY

\section{ChanaRIN, M.D., D.C.P.}

AND

\section{MYRA C. BENNETT, M.A., M.Sc.}

M.R.C. Experimental Haematology Research Unit and Department of Haematology, St. Mary's Hospital, London

The urinary excretion of the pentose D-xylose after an oral dose of $25 \mathrm{~g}$. is widely employed as a test of intestinal absorption (Helmer and Fouts, 1937). A folic-acid absorption test in the form of either a urinary excretion test (Girdwood, 1953) or a tolerance-type test (Chanarin, Anderson, and Mollin, 1958) is less widely employed because microbiological assay methods are required for the measurement of the vitamin.

In investigating patients with megaloblastic anaemia due to folic-acid deficiency, patients were encountered in whom the only evidence of intestinal malabsorption was a test showing impaired folic-acid absorption. In two of these patients the diagnosis of idiopathic steatorrhoea was established by the finding of villous atrophy on jejunal biopsy, but biopsy was normal in four other patients. It is likely that folic-acid deficiency in turn aggravates intestinal malabsorption, and this may be reversed by folic-acid therapy. This appears to be the case in tropical sprue, for after treatment with folic acid tests of intestinal function show a return towards normal (Darby, 1947). Similarly, administration of a folic-acid antagonist interferes with the absorption of xylose in the rat (Zamcheck, 1960). Thus not only may evidence of intestinal malabsorption be minimal but it may be transient. Under these circumstances it would be advantageous to be able to estimate the absorption of D-xylose and folic acid at the same time and under the same circumstances.

This paper reports the results of estimating the serum levels and the urinary excretion after oral doses of folic acid and xylose, given together, in normal subjects and in patients with intestinal malabsorption.

\section{Materials and Methods}

Folic-acid Solution.-A solution of folic acid containing $2 \mathrm{mg}$. $/ \mathrm{ml}$. was prepared in $\mathrm{N} / 5 \mathrm{NaOH}$.

Estimation of Folic Acid.-Folic acid was estimated by microbiological assay using Streptococcus faecalis (A.T.C.C. 8043) as the test organism. The culture medium was that described by Toepfer, Zook, Orr, and Richardson (1951). A widely used commercial dehydrated medium proved unsatisfactory for serum assay, giving recoveries of folic acid added to serum which varied from 140 to $200 \%$.

Estimation of Xylose.-This was by the method of Roe and Rice (1948), barium hydroxide and zinc sulphate being used as a protein-precipitant in serum estimation.

Procedure.-Patients were saturated with folic acid by giving one or more parenteral doses of $15 \mathrm{mg}$. of folic acid, the last injection being given 36 hours before the test. Control subjects were given $10 \mathrm{mg}$. of folic acid by mouth 36 hours before the test. Breakfast was withheld from ward patients, but control subjects were usually tested after a "light breakfast" (coffee and 